\title{
POTENSI INDUSTRI BREGASMALANG - PETANGLONG DALAM MENDUKUNG TERCIPTANYA KLASTER PENDUKUNG DAN BAHAN BAKU INDUSTRI PERTAHANAN INDONESIA
}

\author{
Endro Tri Susdarwono, Aswhar Anis \\ Fakultas Ilmu Sosial dan Ilmu Politik, Universitas Peradaban \\ Korespondensi: saniscara99midas@gmail.com, aswhar.anis@gmail.com
}

\begin{abstract}
The purpose of this study discusses the potential of the Bregasmalang - Petanglong industry in supporting the creation of supporting industry clusters and raw materials for the Indonesian Defense Industry. This research is a qualitative research, the type of research uses a comprehensive analytical study and analytical normative approach. The existing defense industry is expected to form defense industry clusters that drive the country's economic growth. The emergence of defense industry clusters in Indonesia will accommodate the workforce, so the defense industry is expected to contribute to reducing the unemployment rate in Indonesia. In the context of increasing investment and economic growth in the region which has an impact on regional and national economies, accelerated development includes the Brebes-Tegal-Pemalang Regions. To support and provide added value to the development of the area as intended, one of them is the Pekalongan - Batang area, hereinafter referred to as the Petanglong Area. The Defense Industri Law mixes that the defense industry consists of the main equipment industry, the main and supporting component industries, the component and support industries (supplies), and the raw materials industry.
\end{abstract}

Keywords: Bregasmalang-Petanglong, Defense industry, Industrial potential, Raw material industry, Supporting industry

\section{PENDAHULUAN}

Industri dan teknologi pertahanan, hingga saat ini masih ada yang perlu pengaturan untuk peningkatan pemberdayaan industri pertahanan, baik mengenai teknologi yang akan digunakan maupun biaya modal dan pembiayaan secara umum, produksi dan produktivitas dari perusahaan industri pertahanannya sendiri perlu diperhatikan secara seksama dan secara terus menerus. Biaya modal akan terkait dengan keuangan dan perbankan, baik nasional maupun internasional. Kehendak pemerintah untuk benar-benar mengembangkan dan memajukan teknologi dan industri pertahanan harus diimplementasikan pada tingkat pragmatis, dan tidak hanya keinginan semata. Perlu adanya kebijakan dan political will yang dapat mempermudah kalangan industri pertahanan untuk maju (Supriyatno, 2014, p. 102).

Selain itu, unsur pemasaran produk diharapkan tidak hanya dipasarkan kepada sektor pertahanan saja, namun harus dapat menembus pasar dunia. Untuk itu perlu adanya sinergitas dari berbagai pemangku kepentingan untuk meningkatkan teknologi dan industri strategi pertahanan, sehingga dapat memberikan dukungan kepada sektor pertahanan dalam melaksanakan tugasnya mempertahankan eksistensi dan kedaulatan negara serta keselamatan bangsa, selain itu dapat menjadikan perusahaan industri pertahanan menjadi penopang kemajuan ekonomi negara dan bangsa (Supriyatno, 2014, p. 103).

Industri pertahanan seyogyanya adalah concern kita bersama, para pemangku kepentingan di segala lini. Pihak pemerintah, selain menghasilkan regulasi dan menjadi pendukung atau endorser, punya kontribusi vital dalam pengembangan industri pertahanan karena perannya yang luas sebagai pengguna produk-produk industri pertahanan. 
Di pihak lain kalangan industri pertahanan dan masyarakat secara umum misalnya pusat-pusat studi, universitas, serta Lembaga non-pemerintah - juga memegang peran yang cukup besar dalam mengembangkan industri pertahanan. Belajar dari negara-negara yang memiliki industri pertahanan yang sudah maju, well-advanced, bisa kita pahami bagaimana konseptualisasi hubungan pemerintah - industri - masyarakat ikut mempengaruhi tren pertumbuhan ekonomi (Karim, 2014, p. x).

Adanya industri pertahanan yang berkembang diharapkan akan memperluas ketersediaan lapangan kerja. Industri pertahanan yang ada diharapkan akan membentuk klaster-klaster industri pertahanan yang mendorong pertumbuhan ekonomi negara. Munculnya klaster-klaster industri pertahanan di Indonesia mau tak mau akan menampung para tenaga kerja, sehingga industri pertahanan diharapkan berkontribusi terhadap pengurangan tingkat pengangguran di Indonesia (Karim, 2014, p. 89-90).

Hubungan antara pemerintah dan industri pertahanan sesungguhnya sangat krusial. Sudah terbukti kekuatan industri pertahanan suatu negara justru mempengaruhi kebijakan luar negeri suatu negara dan posisinya di tatanan dunia internasional. Walaupun hubungan industri pertahanan dan pemerintah sangat penting, belum banyak analisis tentang hubungan antara pemerintah dan dunia usaha yang berkontribusi terhadap sektor pertahanan.

Hubungan pemerintah dengan industri pertahanan sebenarnya bukan hanya customer atau pembeli dari barang dan jasa yang diproduksi. Pemerintah sebenarnya juga sponsor dan regulator industri pertahanan. Hubungan yang unik ini membuat pemerintah memiliki tiga peran yang berbeda bagi industri pertahanan. Heidenkamp, Louth, dan Taylor menyebutnya sebagai defense industrial triptych (Heidenkamp et all, 2013).
Penelitian ini bermaksud untuk mengulas apa saja yang harus Indonesia kerjakan untuk mendorong pertumbuhan industri pertahanan negara secara optimal. Di antaranya mencakup pemberlakuan sistem klaster yang mengelompokkan industri pertahanan dengan mengacu pada kemampuan suatu daerah dan penguasaan teknologinya hingga keberanian pemerintah mewajibkan proses alih teknologi dari produsen alutsista asing ke industri nasional. Dengan demikian, diskursus yang muncul tidak hanya pada besaran pembelanjaan anggaran, tapi juga mencakup kemampuan menyerap teknologi maju dan mengembangkannya di Tanah Air untuk merintis terwujudnya kemandirian industri pertahanan. Potensi daerah yang ingin dikemukakan adalah wilayah pengembangan Bregasmalang - Petanglong (Kabupaten Pekalongan, Brebes, Pemalang, Batang, Tegal, Kota Pekalongan dan Kota Tegal).

\section{METODE PENELITIAN}

Pendekatan dalam penelitian ini menggunakan pendekatan deskriptif, pendekatan tersebut dimaksudkan untuk memaparkan atau menggambarkan potensi industri Bregasmalang - Petanglong dalam mendukung terciptanya klaster industri pendukung dan bahan baku Industri Pertahanan Indonesia, sedangkan jenis penelitian adalah penelitian deskriptif kualitatif, yaitu mendeskripsikan dan menginterpretasi apa yang ada, itu dapat mengenai kondisi/hubungan yang ada. Pendapat yang sedang tumbuh, proses yang sedang berlangsung, akibat/efek yang tejadi atau kecenderungan yang tengah berkembang.

FGD dilakukan di ruang program studi ekonomi pertahanan Universitas Pertahanan Indonesia 15 - 28 Juni 2019 dengan materi mengenai potensi industri pertahanan di wilayah Indonesia. 


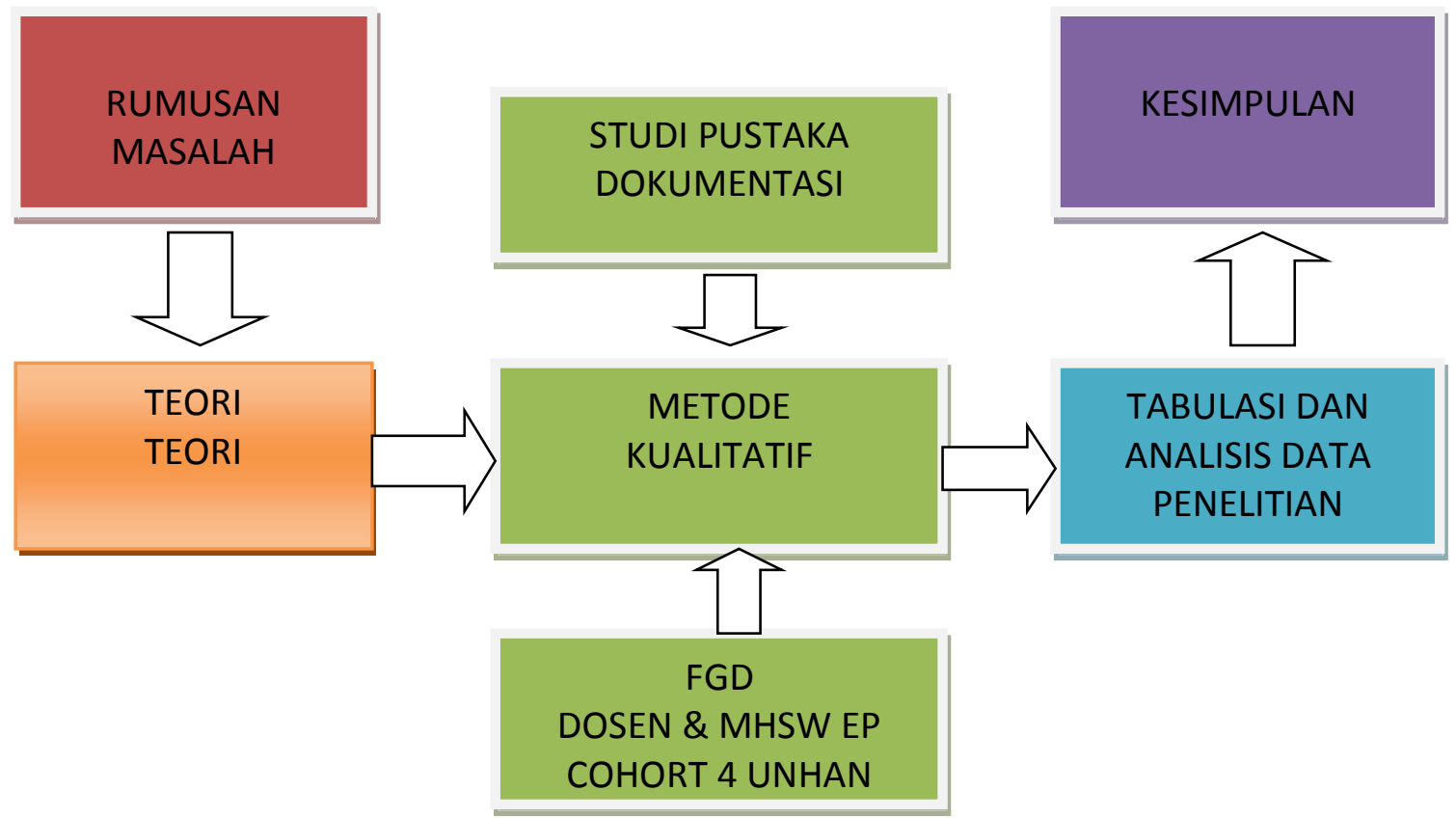

Gambar 1. Alur Berfikir dalam penelitian

Sumber Olahan peneliti

\section{HASIL DAN PEMBAHASAN}

\subsection{Karakter dan Siklus Pematangan} Industri Pertahanan

Integrasi merupakan penggabungan dua atau lebih perusahaan untuk mencapai tingkat efektivitas dan efisiensi produksinya. Baik integrasi maupun merger dapat dilakukan secara vertikal atau horisontal. Vertikal yang dimaksudkan adalah penggabungan perusahaan yang saling berhubungan tetapi tidak sejenis, namun proses produksinya berantai dari hulu ke hilir. Sedangkan untuk horisontal, penggabungan tersebut terjadi karena bentuk usahnya sejenis dalam produk akhir (Yusgiantoro, 2014, p. 183).

Integrasi vertikal dapat dijelaskan sebagai penggabungan dua perusahaan atau lebih yang mempunyai proses produksi berkelanjutan (berantai). Hal ini, akan menjamin ketersediaan komponen alutsista. UndangUndang tentang Industri pertahanan, menjelaskan secara rinci berbagai komponen yang digunakan untuk menghasilkan alutsista. Alutsista yang dihasilkan dari perusahaan yang bergerak pada kegiatan lebih hilir (lead integrator) akan mendapatkan jaminan penyediaan komponen utama, komponen pendukung, dan bahan baku dari perusahaan yang bergerak pada kegiatan yang lebih hulu. Nilai tambah dan harga kompetitif dapat diperoleh dalam integrasi vertikal dengan cara meniadakan berbagai biaya, misalnya biaya transaksi. Tidak banyak dijumpai dalam industri pertahanan yang mengamankan proses produksi berantai dengan prinsip bergabungnya industri yang lebih hulu dalam integrasi vertikal., industri-industri penunjang, seperti industri besi baja, avionik/elektronik, dan mesin untuk membangun kapal perang, jarang melakukan penggabungan hingga terintegrasi secara vertikal relatif kecil apabila dibandingkan dengan biaya yang diperlukan untuk membangun alutsista, contohnya adalah pembangunan kapal perang atau pesawat tempur, di mana porsi biaya terbesarnya terletak pada komponen utama, pendukung, dan bahan baku. Di samping itu, industri pendukung tidak mudah untuk berada dalam lokasi yang berdekatan dengan lokasi industri pertahanan. Gambar 2. menunjukkan keterkaitan suatu industri pertahanan dengan industri hulu dan industri hilir. Efek penggandaan (multiplier effect) terhadap industri hulu disebut dengan keterkaitan ke 
depan (forward linkage) sedangkan terhadap industri hilir disebut dengan keterikatan ke belakang (backward linkage). Secara kuantitatif, dapat diperkirakan seberapa besar keterkaitan ini terjadi, ke belakang dan ke depan. Pada industri pertahanan, forward linkage tidak sebesar dibandingkan dengan backward linkage. Industri hilir dari industri pertahanan banyak dijumpai pada industri jasa, suku cadang, serta pemeliharaan dan perawatan (Yusgiantoro, 2014, p. 183-183).

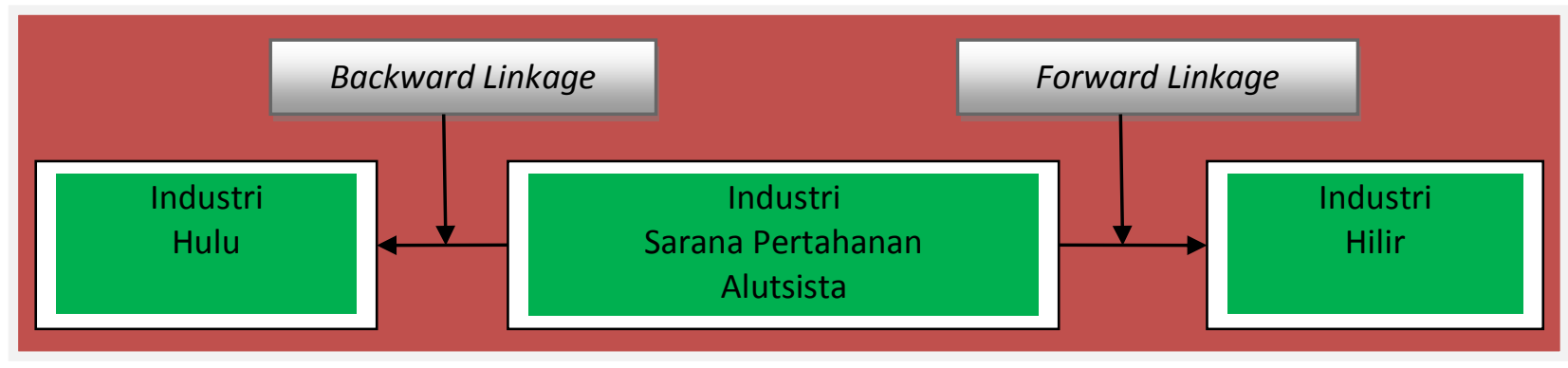

Gambar 2. Efek Pengganda (Multiplier) Ke depan (Forward) dan Ke Belakang (Backward)

Motivasi integrasi vertikal menurut Greer (1984) dapat digunakan untuk riset dan pengembangan; membuka pasar baru yang efisien memastikan ketersediaan bahan baku, dan memastikan akses ke konsumen; melakukan transfer pricing bagi pelaku usaha; serta mengurangi atau menghilangkan pesaing di pasar. Kelebihan dari merger adalah mengurangi biaya penjualan; mengurangi fleksibilitas konsumen dalam pembelian; memperbaiki koordinasi dalam produksi, antar fungsi, dan kapabilitas teknologi; serta melindungi hak kepemilikan. Namun, merger terdapat kekurangan dalam mengintegrasikan berbagai macam operasi dan besarnya beban finansial pada saat memulai usaha.

Integrasi horisontal adalah penggabungan dua atau lebih perusahaan yang mempunyai proses dan hasil produksi yang sama. Perusahaan yang aktif di kegiatan hulu bergabung dengan perusahaan yang melakukan kegiatan hulu, begitu pula dengan perusahaan yang bergerak dalam kegiatan hilir. Dengan integrasi horisontal perusahaan dapat meningkatkan pangsa pasar dan mengurangi biaya, sehingga mampu bersaing dengan perusahaan lain. Kecenderungan ini terjadi dalam industri pertahanan yang menuju ke skala keekonomiannya, seperti yang terjadi di Eropa, penggabungan antara beberapa perusahaan penerbangan yang juga sebagian kegiatannya aktif dalam industri pertahanan, contoh Airbus Military Industry (AMI) yang memproduksi alutsista. Penggabungan juga terjadi dalam pembuatan pesawat tempur, helikopter serang, dan serbu (Yusgiantoro, 2014, p. 185).

Demikian pula, motivasi integrasi horisontal merupakan strategi untuk memperoleh kepemilikan perusahaan dan mengurangi persaingan pasar. Di samping itu, motivasi integrasi horisontal mendapat kelebihan untuk alokasi faktor produksi lebih baik, yaitu pertama, melakukan kontrol atau pengendalian pasar. Kedua, skala keekonomian tiap-tiap unit kerja atau perusahaan, dan dapat mengurangi biaya pemasaran. Selain itu, motivasi integrasi horisontal juga mempunyai kekurangan, yaitu menciptakan ketergantungan, yaitu menciptakan ketergantungan satu dengan lainnya, dan dapat membentuk pasar monopoli.

Pemerintah mempunyai peranan penting dalam membangun industri pertahanan, karena pemerintah merupakan pembeli yang besar atau pembeli tunggal dari peralatan pertahanan yang diproduksi di dalam negeri (monopsoni). Pemerintah dapat menggunakan daya belinya untuk menentukan besaran, kepemilikan, stuktur, proses masuk dan keluar, produk, harga, tingkat efisiensi, dan bahkan profitabilitas industri pertahanan nasional (baik BUMN maupun BUMS). Pemerintah juga dapat mengatur industri pertahanan nasional 
dengan mengendalikan keuntungan pada kontrak pemerintah (misalnya mencegah keuntungan atau kerugian yang berlebihan). Selain itu, pemerintah juga termasuk dapat menentukan harga dan keuntungan dari kontrak nonkompetitif, sehingga dapat mempengaruhi perilaku perusahaan dengan memihak persaingan nonharga (penelitian dan pengembangan), dan dapat mengontrol ekspor senjata, misalnya melalui lisensi (Yusgiantoro, 2014, p. 186).

Menurut Hartley (2007), industri pertahanan mempunyai berbagai karakteristik yang menunjukkan identifikasinya dari segi ekonomi pertahanan. Di antara itu semua, yang menjadi titik sentral seperti layaknya keuangan korporasi, yaitu masalah biaya. Biaya membuat peralatan pertahanan pada umumnya mahal dan cenderung semakin mahal. Biaya pengadaan satu unit pesawat tempur taktis meningkat dengan faktor 2,5 per setiap sepuluh tahun. Perusahaan pembuat senjata akan membuat senjata yang semakin canggih. Setiap pesawat tempur generasi baru, misalnya pesawat tempur generasi 4,5 akan lebih efektif daripada generasi sebelumnya. Biaya pengembangan yang lebih tinggi mengakibatkan jumlah pesawat yang dibeli dari anggaran pertahanan yang terbatas semakin sedikit.

Di samping masalah biaya, terdapat karakteristik lain yang juga penting untuk dicermati dalam kaitan dengan karakter industri pertahanan pada umumnya, yaitu sebagai berikut: (Yusgiantoro, 2014, p. 215216)

1. Kemajuan teknik. Kemajuan teknik menghasilkan produk baru seperti mesin jet, rudal, elektronik, radar, helikopter, dan sistem ruang angkasa, sebagai hasil litbang. Kemajuan teknik ini memengaruhi pasar dan struktur industri pertahanan. Kecenderungan struktural jangka panjang industri pertahanan adalah jumlah perusahaan besar semakin lama semakin sedikit. Hal ini terjadi karena adanya penggabungan dan penutupan perusahaan persenjataan dari industri pertahanan. Kecenderungan ini tampak jelas sejak akhir perang dingin tahun 1990 sampai sekarang.

2. Biaya memasuki bisnis. Mendirikan perusahaan persenjataan memerlukan biaya yang besar untuk pengembangan teknologi dan litbang, ilmuwan yang berkualitas dan tenaga terampil lainnya. Biaya litbang berbeda untuk jenis peralatan yang akan dikembangkan. Beranjak dari sini, dapat disimpulkan bahwa keterlibatan pemerintah dalam industri pertahanan akan menjadi ukuran perkembangan industri pertahanan suatu negara.

3. Ekonomi pembelajaran. Memproduksi senjata secara efisien memerlukan biaya pembelajaran (learning curve), antara lain untuk litbang. Biaya pembelajaran menurun seiring dengan banyaknya senjata yang diproduksi, karena akan memenuhi skala keekonomian. Semakin panjang proses produksi, biaya pembelajaran semakin rendah.

4. Insentif bekerja sama. Kerja sama antara dua atau lebih perusahaan dapat menguntungkan kedua pihak, yaitu melalui berbagi biaya (cost sharing) litbang yang tinggi, skala keekonomian, dan biaya pembelajaran dari proses produksi yang lebih lama. Hal ini karena perusahaan-perusahaan menggabungkan banyak pesanan yang diterima. Kerja sama ini menghasilkan penghematan biaya bagi setiap perusahaan yang terlibat. Kerja sama dalam pembuatan alutsista juga dapat terjadi antara dua negara atau lebih.

5. Restrukturisasi industri. Restrukturisasi industri pertahanan berlangsung bersamaan dengan proses perlucutan senjata yang terjadi sejak berakhirnya Perang Dingin. Perlucutan senjata menyebabkan pembatalan banyak proyek, pesanan yang lebih sedikit, proses produksi yang lebih pendek. Keterlambatan dalam pengiriman produk pesanan, dan pengunduran berbagai program. Restrukturisasi menyebabkan berkurangnya tenaga kerja, penutupan pabrik, penggabungan atau beralihnya 
perusahaan dari bisnis pertahanan ke bisnis lain. Perusahaan juga dapat beralih dari kontraktor utama ke subkontraktor, bergabung dengan perusahaan lain atau dengan perusahaan pertahanan lainnya.

6. Rantai pasokan. Banyak pelaku usaha terlibat dalam industri pertahanan: kontraktor utama, pemasok tingkat pertama, kedua, ketiga, dan seterusnya. Rantai pasokan industri pertahanan yang semakin kompleks menunjukkan semakin tingginya kemampuan teknis subkontraktor, ketergantungan pada program pertahanan, dan kebutuhan tenaga kerja lokal.

7. Strategi penyesuaian. Perkembangan teknologi dan gejolak eksternal memerlukan strategi penyesuaian yang tepat bagi setiap perusahaan. Perubahan teknologi yang drastis terjadi ketika mesin piston digantikan dengan mesin jet, pesawat berawak digantikan dengan rudal dan penerbangan antariksa tak berawak. Perubahan teknologi yang dikembangkan untuk kepentingan militer dapat diterapkan pada industri komersial (nonmiliter). Perubahan teknologi membutuhkan sumber daya litbang untuk berinovasi dalam pasar militer dan sipil, sedangkan gejolak eksternal terjadi antara lain karena perang. Gejolak ini menyebabkan permintaan untuk peralatan dan persenjataan meningkat. Ekspansi industri pada masa perang, kemudian mengalami kontraksi ketika perang selesai, yang menyebabkan produksi kembali ke kondisi masa damai. Agar bisa bertahan, setiap industri pertahanan harus menyesuaikan dirinya dengan ketidakpastian yang timbul dari perubahan teknologi dan gejolak eksternal.

Terdapat beberapa model atau pendekatan mengenai siklus pematangan suatu industri, namun dalam pembahasan ini akan dilakukan berdasarkan pendekatan empiris. Pendekatan empiris ini hampir sama dengan yang diperkenalkan oleh Vernon dan Holland. Vernon lebih banyak menjelaskan pada penahapan proses dari pembentukan awal industri sampai pada tahap orientasi ekspor, sedangkan Holland menekankan pada proses proteksi di awal pembentukan industri dengan menggunakan kebijakan fiskal. Secara terinci, siklus perkembangan industri pertahanan pada umumnya dapat dijelaskan sebagai berikut:

1. Tahap awal produksi (infant industry): perusahaan dalam rangka mendukung pembangunan kekuatan pertahanan, mulai berproduksi untuk memenuhi kebutuhan sarana pertahanan dalam negeri, sedangkan kekurangannya dipenuhi dengan impor. Pada tahap ini, pemerintah memberikan proteksi, sehingga industri mampu bersaing. Proteksi yang diberikan pemerintah dapat berupa insentif fiskal atau penyertaan modal pemerintah apabila perusahaan tersebut adalah BUMN. Dengan pemberian insentif, perusahaan domestik mampu menghasilkan barang dengan harga relatif murah dibandingkan perusahaan asing, sehingga perusahaan domestik mampu bersaing. Masalah yang selalu timbul dalam pemberikan proteksi adalah batas waktu dan kapan proteksi tersebut harus dibuka. Pemberian batas waktu menjadi penting karena tidak hanya dapat mendorong industri domestik agar mempunyai rencana yang jelas dan matang, sehingga efisien, tetapi juga karena tekanan internasional dalam era globalisasi yang menolak segala bentuk proteksi.

2. Tahap substitusi impor (import substitution): industri pertahanan berusaha untuk meningkatkan kualitas produksinya sambil melakukan substitusi impor dalam rangka memproduksi sendiri sarana pertahanannya. Substitusi impor ini dapat dilakukan dengan upaya alih teknologi dan meningkatkan kadar kandungan lokal melalui peningkatan kemampuan industri ke arah hulu, seperti industri yang terkait dengan bahan baku, dan avionik/ elektronik. Negara dengan kemampuan teknologi yang terbatas, akan mengembangkan industrinya pada alutsista dengan tingkat teknologi tertentu dan tetap melakukan impor terhadap alutsista yang kadar teknologinya tinggi (contohnya helikopter serang Apache, 
pesawat tempur F-35, dan kapal selam). Pada tahap ini, adakalanya suatu negara tidak memerlukan industri pertahanan yang lebih matang karena sarana pertahanan yang dimiliki sudah cukup mampu untuk menanggulangi ancaman yang timbul. Dengan demikian, tidak diperlukan langkah-langkah untuk mengembangkan substitusi impor.

3. Tahap orientasi ekspor (export orientation): sarana pertahanan yang sudah dapat diproduksi sendiri, kemudian dibuat standardisasi dan sertifikasi, selanjutnya diupayakan bekerja sama dengan perusahaan luar negeri dengan orientasi untuk ekspor. Setelah mampu berproduksi di dalam negeri, perusahaan tersebut akan menjadi perusahaan dominan dalam struktur pasar monopolis di dalam negeri atau oligopoli di luar negeri. Apabila perusahaan tersebut mampu menjadi dominan karena mempunyai keunggulan pengalaman dan inovasi teknologi yang dimiliki, maka akan dapat bersaing dengan perusahaan lain yang baru muncul di pasar luar negeri.

4. Tahap pematangan industri (matured industry): selama jangka waktu ini perusahaan domestik akan tumbuh dewasa, dan dapat bersaing. Secara bertahap proteksi mulai dikurangi, dan akhirnya ditiadakan sama sekali. Pada saat inilah, perusahaan domestik sudah cukup mampu bersaing dengan perusahaan asing. Adakalanya perusahaan bekerja sama dengan perusahaan lain di luar negeri untuk merebut pasar, bahkan dapat saja melakukan relokasi ke luar negeri untuk mendapatkan faktor produksi yang lebih kompetitif sambil merebut pasar. Pada awal proses internasionalisasi, perusahaan luar negeri hanya ditunjuk sebagai representatif yang secara bertahap dapat diberikan lisensi. Bentuk akhir keterlibatan perusahaan dalam memproduksi barang di negara lain, yaitu dengan melakukan investasi langsung.
Dalam perkembangannya, dapat saja perusahaan luar negeri melakukan FDI tanpa harus melalui urutan penunjukan representatif dan lisensi terlebih dahulu.

\subsection{Industri Pertahanan Indonesia}

Industri pertahanan telah menjadi salah satu bentuk fenomena globalisasi. Perkembangan industri pertahanan di luar negara kutub dalam perang dingin, yaitu Amerika Serikat dan Rusia, semakin maju. Negara-negara Eropa, Tiongkok, Jepang, juga negara seperti India dan Israel telah mengembangkan industri pertahanannya dengan baik. Adanya industri pertahanan yang maju dan berkembang terbukti mampu memberikan sumbangan bagi perekonomian suatu negara (Karim, 2014, p. 85).

Salah satu bentuk keuntungan utama jika Indonesia memiliki industri pertahanan yang maju dan mandiri adalah keuntungan secara ekonomi. Industri pertahanan yang maju di Indonesia diharapkan akan memberikan sumbangan bagi pertumbuhan ekonomi Indonesia, sebagaimana industri manufaktur, yang selama ini mampu menjadi penyumbang terbesar PDB Indonesia. Industri pertahanan yang sehat juga akan mendorong adanya klaster-klaster industri yang bisa memberikan efek domino pertumbuhan ekonomi. Efek posistif adanya klaster-klaster industri pertahanan akan dirasakan daerah-daerah, di mana akan terjadi penyebaran potensi ekonomi secara lebih mendalam.

Keuntungan ekonomi dari adanya industri pertahanan dalam negeri yang lain adalah potensi ekspor. Pasar senjata dan peralatan pertahanan di dunia masih terbuka luas. Dengan komitmen serius untuk mencari dan memiliki keunggulan kompetitif tertentu, Indonesia bisa memanfatkan industri pertahanan sebagai salah satu komoditas ekspor yang bisa menyumbangkan devisa bagi negara. Jika selama ini Indonesia lebih banyak berperan sebagai importir dalam industri pertahanan, peluang dan tekad sebagai eksportir alat-alat pertahanan pun harus dimanfaatkan dan diupayakan. 


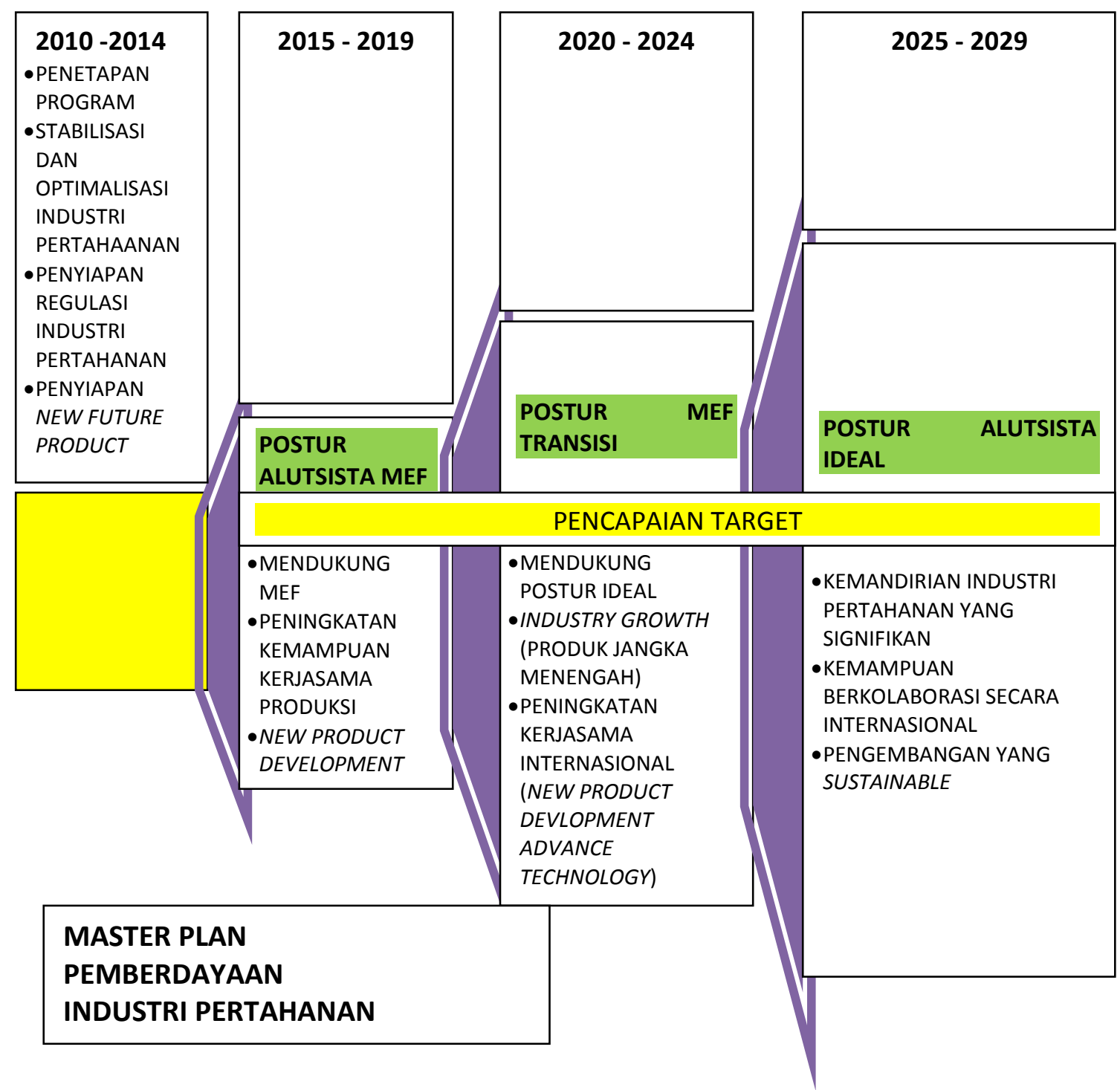

Gambar 3. Rencana Pengembangan Postur Alutsista dan Industri Pertahanan Sumber: Komite Kebijakan Industri Pertahanan (2014)

Dalam rencana pengembangan postur alutsista dan industri pertahanan, pemerintah mengaitkan rencana pengembangan postur alat utama sistem senjata (alutsista) dengan program pencapaian kemandirian industri pertahanan. Gambar 3 menjelaskan arah pengembangan postur alutsista yang didasari program pengembangan industri pertahanan dalam negeri. Selama 2010-2014, misalnya, tahapan stabilisasi dan optimalisasi industri pertahanan, penyiapan regulasi industri pertahanan, serta penyiapan alutsista baru di masa depan (future weapon) sengaja diarahkan untuk mendukung postur sesuai dengan Minimum Essential Force (MEF).

Sedangkan dalam fase kedua 2015-2019, pengembangan indusri pertahanan sengaja diarahkan untuk memiliki kemampuan kerja sama produksi dan pengembangan produk baru (product development), seperti medium tank, roket, dan kapal selam, guna mendukung pencapaian MEF dan meraih postur kekuatan pertahanan yang ideal. Sedangkan dalam fase 2020-2024, untuk mndukung postur militer yang ideal, industri harus mampu tumbuh secara signifikan (industrial growth) dan mampu memproduksi alutsista berteknologi 
cangih lewat kerja sama internasional (product development-advance technology).

Pada ujungnya pemerintah menyadari postur kekuatan pertahanan yang ideal yang diharapkan akan tercapai pada rentang waktu 2025-2029, tidak akan bisa dicapai tanpa industri pertahanan yang mandiri, memiliki kemampuan teknologi untuk berkolaborasi secara internasional, serta mempunyai kemampuan pengembangan produksi yang berkelanjutan (sustainable). Catatan penting untuk digarisbawahi, tujuan akhir pengembangan industri pertahanan tidak hanya untuk memenuhi kebutuhan alutsista dalam negeri, tapi juga menerobos pasar ekspor untuk bersaing secara internasional, dan menjadikan sektor industri pertahanan sebagai salah satu pendorong utama pertumbuhan ekonomi (economic growth support) (Karim, 2014, p. 2020).

Karena itu, upaya pengembangan industri pertahanan berdaya saing tinggi dengan dukungan $R \& D$ yang mapan sangat penting. Bukan saja untuk menghadapi ancaman keamanan, tapi juga membuat Indonesia tetap relevan dalam persaingan sengit di era globalisasi ekonomi ke depan. Caranya dengan membangun ketangguhan daya saing lewat basis industri manufaktur berteknologi canggih.

Strateginya sudah jelas: mengoptimalkan nilai tambah dari industri pertahanan. Untuk itu, langkah awal yang harus dilakukan adalah mendorong subsitutsi impor untuk industri pertahanan dan setelah industri berkembang, langkah akhirnya adalah mengupayakan komersialisasi atau spin off dari efek lanjutan (spillover effect) atau efek pengganda (multiplier effect) industri pertahanan berupa produk yang bisa digunakan untuk kepentingan sipil. Dukungan untuk langkah awal strategi ini harus berangkat dari kebijakan

\subsection{Pembinaan Industri Utama dan Pendukung Industri Pertahanan}

Kebijakan mengenai industri pertahanan di Indonesia sudah jelas dengan diundangkannya Undang-Undang Nomor 16 Tahun 2012 tentang Industri Pertahanan. Undang-Undang tersebut memberikan garis besar bahwa industri pertahanan terdiri atas industri alat utama, industri komponen utama dan penunjang, industri komponen dan pendukung (perbekalan), serta industri bahan baku. Dari awal, pemerintah sudah mengatur bahwa BUMN pertahanan menjadi industri alat utama sekaligus pemadu utama (lead integrator) yang menghasilkan alat utama sistem senjata dan/atau mengintegrasikan semua komponen utama, komponen, dan bahan baku menjadi alat utama. Pemerintah menutup rapat pintu investasi swasta di industri alat utama. Sebab, Undang-Undang Nomor 16 Tahun 2012 mengatur bahwa modal atas industri alat utama seluruhnya dimiliki negara. Sedangkan modal atas industri komponen utama/penunjang, industri komponen/pendukung (perbekalan), dan industri bahan baku, yang merupakan badan usaha milik negara, paling rendah 51 persen dimiliki negara (Pasal 52 Undang-Undang Nomor 16 Tahun 2012 tentang Industri Pertahanan).

Ada beberapa BUMN yang posisinya harus menjadi pemadu utama. BUMN yang sudah ada, seperti PT Dirgantara Indonesia (DI), bisa menjadi lead integrator untuk pesawat tempur, pesawat terbang, atau helikopter. Dengan begitu, BUMN tersebut akan menjai pemadu utama klaster industri pertahanan sub-cluster pesawat terbang, baik fixed-wing maupun rotary, baik tempur maupun angkut. Sedangkan PT. Pindad akan menjadi pemadu utama untuk produk senjata dan kendaraan tempur. Pindad akan menjadi lead integrator klaster industri pertahanan subklaster kendaraan tempur dan senjata. Adapun PT. PAL menjadi pemimpin untuk klaster industri pertahanan kapal kombatan, subklaster kapal perang atas air dan kapal selam (Karim, 2014, p. 235).

Industri komponen utama/penunjang adalah BUMN, namun juga boleh Badan Usaha Milik Swata (BUMS). Industri komponen utama/penunjang memproduksi komponen utama atau mengintegrasikan komponen atau suku cadang dengan bahan baku menjadi komponen utama alpalhankam (alat peralatan pertahanan dan keamanan) atau platform sistem alutsista. Sedangkan industri komponen/pendukung

(perbekalan) 
memproduksi suku cadang untuk alat utama sistem senjata, suku cadang untuk komponen utama, dan/atau yang menghasilkan produk perbekalan. Adapun industri bahan baku memproduksi bahan baku yang akan digunakan oleh industri alat utama, industri komponen utama/penuinjang, dan industi komponen/pendukung (perbekalan).

Kalau melihat perusahaan produsen alat pertahanan yang sekarang ada, klaster industri pertahanan yang diharapkan sebenarnya belum terbentuk. Ada beberapa BUMN yang bisa menjadi industri komponen utama/penunjang atau komponen pendukung. PT. Dahana, misalnya, yang memproduksi bahan peledak dan bom. Ada juga PT. LEN yang memproduksi alat komunikasi, baik manpack, base station, maupun mobile, alat surveillance, combat management system, dan sistem listrik tenaga surya. Sedangkan PT. Inti membuat surveillance system, next generation video messaging system, dan sejenisnya. Jangan lupakan PT. Krakatau Steel, BUMN yang memproduksi baja berbagai jenis, bisa menjadi salah satu industri penunjang dan pendukung. Adapun PT. Barata Indonesia memproduksi bomb basket, smart bomb, dan alat-alat berat (Karim, 2014, p. 236).

Menurut Karim (2014) kondisi riil industri pertahanan sekarang ini, BUMN yang lain belum diarahkan menjadi bagian dari klaster penunjang dan pendukung. PT. Inka, yang memproduksi gerbong penumpang dan barang; PT. Boma Bisma Indra, yang memproduksi peralatan pembangkit tenaga listrik dan peralatan pabrik; serta PT. Dok Perkapalan Koja Bahari, PT. Dok Perkapalan Surabaya, dan PT. Industri Kapal Indonesia, yang memproduksi landing ship, kapal patroli, kapal kargo, kapal ikan, kapal tunda, dan repowering KRI, harus disinergikan untuk menciptakan klaster industri alat utama. Melihat keterbatasan BUMN pertahanan, upaya menciptakan klaster industri pertahanan harus melibatkan BUMS.

Saat ini ada beberapa BUMS produsen alpalhankan, yakni CV. Sari Bahari, yang memproduksi bom udara latih, PT. Daya Radar Utama (kapal angkut tank), PT. Lundin Invest (wahana kapal cepat rudal trimaran dan catamaran), PT. Palindo (wahana kapal cepat rudal 40 meter dan kapal patroli), PT. Sentra Surya Ekajaya (rantis), PT. Infoglobal (avionics), PT. CMI (radar, VSAT untuk ground segment satelitte), PT. Langit Biru (payung udara orang), PT. Saba Wijaya (helm anti peluru), PT. Maju Mapan (tenda lapangan), PT. Sritex dan PT. Famatex (pakaian dinas, kain pakaian dinas, kain), serta PT. Jangkar (ransum/makanan) (Karim, 2014, 237-238).

Masalahnya, kebanyakan BUMS ini belum diarahkan menjadi bagian dari klaster industri pertahanan yang mampu memproduksi komponen penunjang dan pendukung atau bahan baku. Seperti BUMN non-pemadu utama, kebanyakan BUMS tidak memproduksi barang yang sesuai untuk menyusun klaster yang terpadu. Sebagian BUMS ini memproduksi barang jadi yang berada di luar klaster industri yang diharapkan atau memproduksi alpalhankam yang mirip atau overlapping dengan produk industri alat utama sebagai lead integrator.

Sampai di sini terlihat fokus industri pertahanan kita masih mengejar aspek penguasaan teknologi dengan menjadi endproduct assembler yang mampu memproduksi sistem senjata yang semakin kompeks dan canggih. Pada saat bersamaan, kita berusaha meningkatkan muatan lokal dengan mengembangkan industri lokal komponen penunjang dan pendukung di dalam negeri. Puncak tangga produksi adalah kemampuan memproduksi sistem senjata yang canggih hasil karya rekayasa sendiri, dengan seluruh komponen penunjang dan pendukung diproduksi di dalam negeri.

Karena itu, tidak bisa tidak, penting untuk membangun keselarasan dengan klaster industri sipil di dalam negeri, terutama industri manufaktur. Premis utama yang harus disadari, industri pertahanan adalah bagian dari industri nasional. Upaya membangun industri pertahanan akan sangat terkait dan sangat bergantung pada perkembangan klaster-klaster industri sipil nasional secara keseluruhan. Kembali merujuk ke ulasan awal, secara mudah kita bisa melihat, negara yang memiliki industri pertahanan yang maju juga merupakan 
negara dengan basis industri manufaktur yang kuat.

\subsection{Potensi Industri Bregasmalang- Petanglong dalam Membentuk Klaster Industri Komponen/Pendukung dan Bahan Baku Industri Pertahanan Indonesia}

Kemandirian yang paling penting dalam industri pertahanan merupakan fase industri yang mampu mandiri dalam membuat dan mengembangkan alutsista. Indonesia memiliki keleluasaa $\mathrm{n}$ dalam rangka mewujudkan kemandirian dalam membuat alutsista pertahanan Indonesia jika dilihat dari sisi politik karena merupakan negara netral yang tidak memiliki konflik serius dengan negara lain dan tidak mengalami tekanan internasional. Di luar adanya berbagai barrier seperti minimnya resources, baik secara keuangan, infrastruktur, SDM, maupun teknologi, faktor keleluasaan tersebut harus terus dimanfaatkan dengan baik.

Karim (2014) berpendapat sebenarnya kemandirian dalam membuat ini sudah lama ada dan dimanfaatkan Indonesia. Berbagai pelaku industri pertahanan di Indonesia terus memproduksi berbagai produk pertahanan hingga kini, terutama melalui skema-skema kerja sama, seperti kerja sama Airbus dengan PT. DI dan PT. Pindad dengan FNSS Turki.

Perwujudan kemampuan kemandirian dalam membuat peralatan pertahanan harus terus dimanfaatkan dan dikembangkan. Dengan membuat sendiri alat-alat pertahanan, Indonesia akan mendapat berbagai keuntungan, dari keuntungan ekonomi berupa munculnya klaster-klaster industri pertahann yang akan membantu mendorong pertumbuhan ekonomi, menyediakan banyak lapangan kerja, dan meningkatkan kemampuan teknologi, hingga keuntungan kekuatan pertahanan Indonesia (kekuatannya menjadi lebih tidak mudah dibaca dibanding jika menggunakan berbagai alutsista dari negara lain)

Terkait dengan pembangunan yang nyata dan dihubungkan dengan penggalian potensi industri komponen/pendukung dan bahan baku industri pertahanan kawasan daerah, peningkatan investasi dan pertumbuhan ekonomi kawasan yang berdampak pada perekonomian regional dan nasional, maka upaya yang dilakukan dengan wujud percepatan pembangunan di antaranya Kawasan Brebes - Tegal - Pemalang. Untuk mendukung dan memberikan nilai tambah pembangunan kawasan sebagaimana dimaksud dilakukan pengembangan salah satunya Kawasan Pekalongan - Batang, yang selanjutnya disebut Kawasan Petanglong (Pasal 1 Peraturan Presiden Republik Indonesia Nomor 79 Tahun 2019).

Menurut Yusgiantoro (2014) dalam teori ekonomi industri, setiap klaster industri memiliki keterkaitan (linkages) dengan sektor industri yang lain. Ada dua jenis linkages. Pertama, backward linkages atau keterkaitan ke belakang, yang berarti sektor industri lain menyumbang input ke industri pertahanan dari output produk mereka. Yang kedua, forward linkages atau keterkaitan ke depan, yang menunjukkan output industri pertahanan bisa menjadi input bagi klaster industri lainnya. Kalau kemandirian industri pertahanan menjadi tujuan kita bersama, upaya sinkronisasi backward linkages harus menjadi sasaran penting. Inilah yang disebut local commercial off the shelf, yakni, membeli barang dari industri sipil swasta yang diproduksi di pasar dalam negeri sebagai input dalam produksi industri pertahanan. Secara umum, diagram hubungannya bisa dilihat dalam gambar infografis 4 (Karim, 2014, p. 245) 


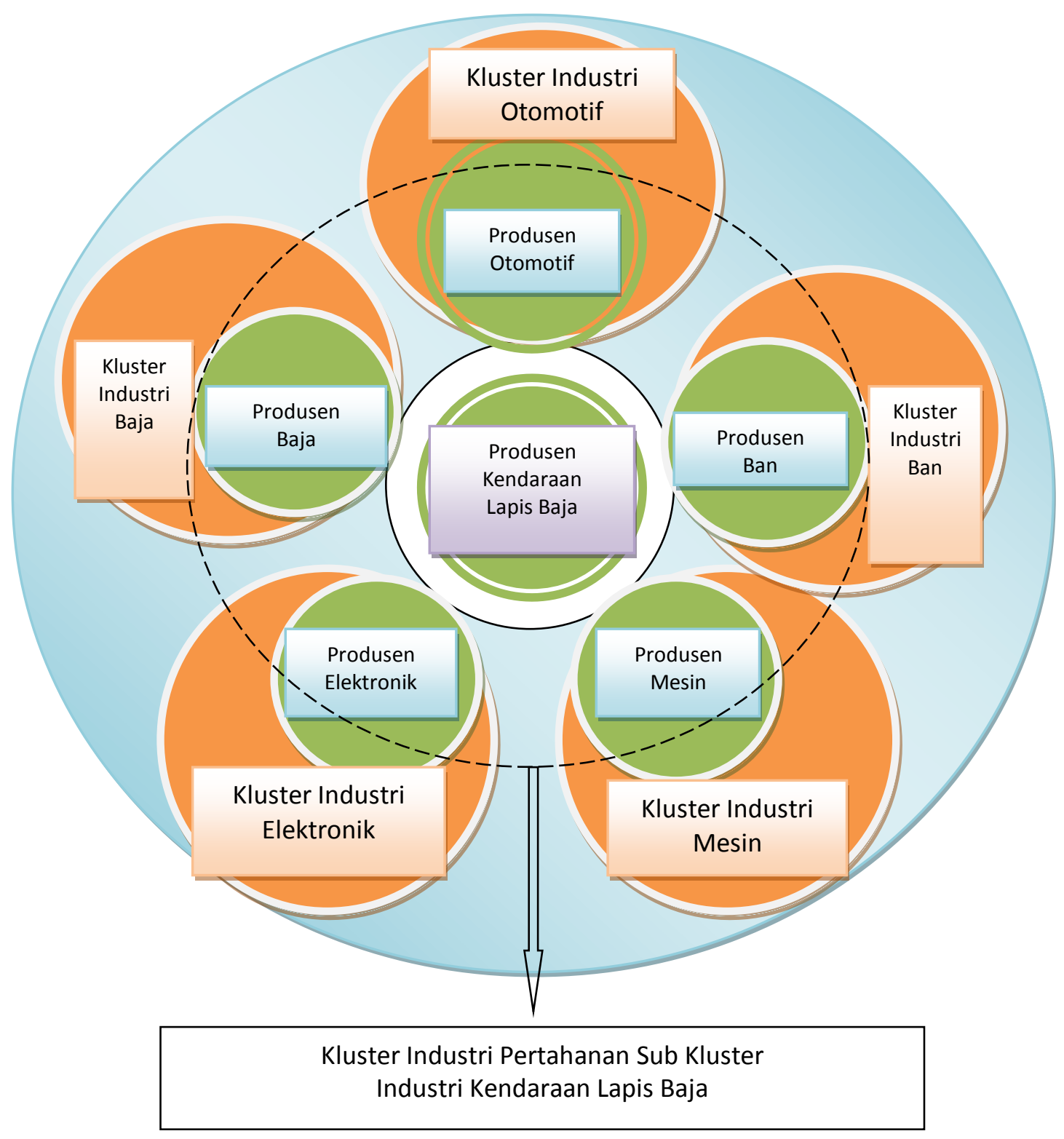

Gambar 4. Linkages Industri Pertahanan dan Klaster Industri Sipil

Ambil contoh alutsista berupa armored personnel carrier (APC) yang diproduksi oleh industri pertahanan yang menjadi lead integrator sub-cluster kendaraan lapis baja. Kendaraan lapis baja ini memerlukan komponen karoseri baja, ban, elektronik, dan mesin. Kalau semua komponen ini hendak diambil dari perusahaan lokal, produsen kendaraan tempur lapis baja yang menjadi pemadu utama klaster industri alat utama tank dan kendaraan tempur harus didukung oleh industri komersial swasta, yakni produsen baja, perusahaan otomotif dan karoseri, perusahaan ban, produsen mesin, serta perusahaan elektronik. Masalahnya, setiap perusahaan ini berada di klaster pembinaan industri yang berbeda.

Dalam cetak biru "Pengembangan Klaster Industri Prioritas Basis Industri Manufaktur" yang disusun pemerintah, (Kementerian Perindustrian, Road Map Pengembangan Klaster Industri Prioritas Basis Industri Manufaktur Tahun 2010/2014 (Jakarta: 2009), perusahaan baja masuk klaster industri baja 
nasional, perusahaan otomotif dan karoseri masuk klaster industri otomotif, produsen mesin masuk klaster industri mesin dan peralatannya, perusahaan elektronik masuk klaster industri elektronik, dan perusahaan ban masuk klaster industri karet dan olahannya.

Tantangannya adalah menyinergikan irisan keterkaitan industri (industrial linkages), yang melibatkan klaster industri nonpertahanan, agar mampu memproduksi barang komersial yang sesuai dengan kebutuhan industri pertahanan. Selain itu, pembinaan klaster industri komersial lainnya juga harus terintegrasi, selaras, dan sesuai dengan tahapan pembentukan klaster industri pertahanan, misalnya dengan memfokuskan kemandirian industri agar mampu memproduksi seluruh produk dan tahapan mata rantai pertambahan nilai (value-chain) dari hulu ke hilir (Karim, 2014, p. 247-248).

Negara harus membangun struktur industri pertahanan dan industri nasional yang kuat. Ini berarti hadirnya produk pohon industri yang dalam dan lengkap, dari poduk hulu di industri sipil komersial hingga produk hilir di industri pertahanan. Kata kuncinya adalah membangun keseimbangan pembangunan industri pertahanan dan indistri komersial dalam negeri. Semakin kuat keterkaitan klaster industri pertahanan dan klaster industri sipil komersial, semakin kuat dan terkoneksi pula sumbangan nilai tambah dari setiap klaster. Harapannya, semakin terintegrasi linkages produk hulu di industri sipil komersial hingga produk hilir industri pertahanan. (Karim, 2014, p. 248-249).

Langkah awal yang bisa dilakukan adalah menyusun peta kondisi dan situasi industri nasional serta klaster industri sipil terkait. Sampai seberapa dalam struktur klaster industi ke hulu, sampai seberapa jauh penguasaan setiap klaster industri terhadap mata rantai produk pohon industri, berapa tingkat kandungan lokal untuk setiap tahapan mata rantai pertambahan nilai, ini semua harus dapat dipetakan. Dari sini bisa disusun database klaster indutri pertahanan. Hadirnya database ini menjamin ketersediaan informasi yang akurat dalam analisis dan pengambilan kebijakan dalam rencana pengembangan industri pertahanan (Karim, 2014, p. 248).

Pemerintah juga harus membina dan menguatkan keterkaitan klaster industri pertahanan dan klaster industri sipil dalam berbagai skala usaha. Penguatan hubungan antar klaster industri harus melibatkan mulai jaringan perusahaan multinasional yang berada di dalam klaster industri sipil sampai jaringan usaha kecil dan menengah (UKM) yang menjadi industri penunjang klaster industri komersial yang terkait. Termasuk penguatan hubungan dengan kegiatan sektor jasa yang mendukungnya.

Pemerintah sendiri sudah berencana mengembangkan industri komponen penunjang dan pendukung. Kementerian Perindustrian umpamanya, sudah merencanakan agar PT. Indonesia Asahan Aluminium (Inalum), BUMN yang baru diambil alih kepemilikannya dari perusahaan Jepang, memproduksi produk hilir aluminimum seperti komposit komponen pembuatan pesawat terbang. Hilirisasi akan dilakukan secara bertahap, dari produk setengah jadi hingga kualias paling tinggi yang biasa digunakan untuk produksi barang berteknologi tinggi seperti kapal dan pesawat terbang.

Potensi yang dapat dikembangkan di Kabupaten Brebes dilihat dari kegiatan industri yang dibagi menjadi beberapa kelompok dan cabang yaitu kelompok industri formal cabang agro, kelompok indutri formal cabang tekstil dan kelompok indutri formal cabang logam, mesin dan elektronik. Industri yang ada di Kabupaten Brebes meliputi industri besar, industri sedang, industri kecil dan industri rumah tangga. Kelompok industri besar merupakan industri formal agro (pabrik teh, pabrik jamur, pabrik gula dan gondorukem). Kelompok industri kecil yang ada di Kabupaten Brebes meliputi industri kecil formal dan non formal. Kelompok industri kecil formal terdiri dari cabang industri agro; elektronika dan aneka; mesin, logam, dan perekayasaan. Sedangkan kelompok industri non formal meliputi industri kimia, agro dan hasil hutan serta elektronika dan aneka. Kelompok industri kecil yang ada di 
Kabupaten Brebes meliputi industri kecil formal dan non formal. Kelompok industri kecil formal terdiri dari cabang industri agro; elektronika dan aneka; mesin, logam, dan perekayasaan. Sedangkan kelompok industri non formal meliputi industri kimia, agro dan hasil hutan serta elektronika dan aneka. Sektor industri yang potensial untuk dikembangkan adalah industri garam iodium di wilayah Kecamtan Wanasari dan Bulakamba, Industri garam curah dengan sentra produksi di wilayah Kecamatan Losari, Tanjung, Wanasari dan Brebes, serta industri pengolahan bawang merah dan telur asin.

Terlebih Presiden Jokowi telah menetapkan Kabupaten Brebes sebagai salah satu kawasan industri nasional melalui Kawasan Industri Brebes dan Kawasan Peruntukan Industri Brebes pada November 2019 lalu. Direncanakan, kawasan industri akan terbentang dari Kecamatan Losari, Tanjung hingga Bulakamba. Brebes tidak hanya dilirik para investor, tapi para investor sudah menambatkan hatinya dengan bukti menanamkan investasi dengan nilai yang sangat tinggi. Terhitung hingga akhir Desember 2019 sebanyak 24 investor yang telah mendirikan pabrik di Kabupaten Brebes. Dan akan terus berkembang, karena yang masih dalam proses perizinan sebanyak 12 perusahaan.

Kehadiran KIB dan KPIB selain membuka kran investasi seluas-luasnya juga ada peran dari pemerintah pusat dan provinsi. Yakni dengan dipenuhinya berbagai sarana dan prasarana penunjang KIB dan KPIB. Seperti penyelesaian jalan lingkar utara (jalingkut) Wanasari - Kota Tegal, dan nantinya dilanjutkan jalingkut Wanasari - Losari. Juga pembangunan bendungan karet di empat sungai, yakni Kali Pemali, Kali Kabuyutan, Kali Cisanggarung dan Kali Babakan. Selain itu juga akan ditunjang dengan Pembuatan Balai Latihan Kerja dan Pembangunan Politeknik Vokasi. Untuk mengatasi terjadinya rob dan abrasi, akan dibangun tanggul penahan rob dan abrasi di sepanjang pesisir pantai Brebes, Wanasari, Bulakamba, Tanjung dan Losari (http://www.brebeskab.go.id)
Keberadaan sentra industri komponen kapal di Kota Tegal, Jawa Tengah (Jateng), diperkirakan akan mengalami geliat yang cukup membawa efek nasional. Terutama dalam memenuhi berbagai order dari industri galangan kapal di Tanjung Uncang, Batam. Pasalnya, pasokan untuk berbagai jenis komponen kapal dari Kota Bahari tersebut, akan dipakai untuk memenuhi berbagai kebutuhan komponan kapal di daerah ini, yang jumlahnya mencapai 70 industri galangan kapal eksisting. Bukan hanya itu, potensi pasokan untuk berbagai jenis komponen kapal bagi pembangunan kapal-kapal baru dan reparasi di Tanjung Uncang - yang rata-rata dibangun dalam jumlah series - nilainya mencapai puluhan triliun rupiah.

Saat ini, UD. Setia Kawan yang merupakan industri perkapalan memasok berbagai komponen kapal bagi galangan PT. Daya Radar Utama, PT. Sanur Marindo Shipyard, PT. Citra Bahari, PT. Lintas Bojonegoro Nusantara, PT. Janata dan galangan kapal lainnya. Sentra industri komponen kapal UD. Setia Kawan metal casting \& ship equipment adalah perusahaan swasta dengan spesialisasi pembuatan komponen kapal laut (marine/ship equipment). Beberapa komponen kapal yang diproduksinya meliputi side scuttle, square window, gate valve, handel pintu kedap, air pipe head, jangkar, clino meter.

Kota Tegal hingga kini masih menjadi basis industri komponen mesin di Tanah Air. Kota pesisir Utara Jawa Tengah ini banyak memiliki industri komponen yang mampu memasok komponen mesin ke berbagai industri besar. Tegal sebagai pusat machining industry, karena pertumbuhan dan perkembangan sekian lamanya Tegal punya kekuatan menyuplai komponen alat berat, otomotif, perkapalan, alat kesehatan, alat pertanian.

Saat ini setidaknya ada 7.541 IKM logam, yang mampu menyerap tenaga kerja hingga 36.200 orang. Dari pelaku IKM itu mencakup $71 \mathrm{IKM}$ industri logam alat berat, 52 IKM industri otomotif dan elektronika, 10 IKM industri kapal, 13 IKM industri alat kesehatan dan 13 IKM industri alat pertanian. 
Kementerian Perhubungan sejak tahun 2011 telah berupaya membangun Pelabuhan Niaga. Pada tahun 2013 pelaksanaan pembangunan memasuki tahap III dengan target output berupa groin sheetpile sepanjang 105 meter berbiaya Rp. 10 milyar. Proses pembangunan yang ditargetkan selesai pada tahun 2015 ini akan mengubah kolam pelabuhan menjadi lebih dekat dengan laut lepas. Dengan demikian, diharapkan di masa datang Pelabuhan Tegal tidak hanya menjadi sarana singgah kapal-kapal niaga dan nelayan, tapi juga menjadi tempat singgah kapal penumpang. Harapan ini bukannya tidak mungkin, mengingat Pelabuhan Tegal telah terdaftar di International Maritim Organization (IMO, Organisasi Kemaritiman Internasional).

Nilai transaksi dari industri komponen kapal ini sangat besar, jadi bagaimanapun caranya industri komponen lokal, harus bisa mengambil peluang yang besar ini. Sebenarnya industri komponen untuk kapal ini bisa dibuat di industri dalam negeri, khususnya di Tegal, Jawa Tengah, namun ada beberapa kendala yang cukup berat, seperti biaya pengiriman dari Tegal ke Batam jauh lebih mahal dibanding dari Singapura. Demikian juga waktu pengiriman. Impor dari Singapura pengirimannya hanya hitungan jam sementara dari Pulau Jawa bisa berminggu-minggu. Oleh karena itu, Pemerintah setempat bertekad akan memajukan industri komponen lokal dan berkoordinasi dengan beberapa kementerian terkait untuk mengatasi masalah tersebut, sehingga kebutuhan komponen kapal ini bisa dipasok dari dalam negeri.

Industri Kecil dan Menengah (IKM) logam Kabupaten Tegal memiliki potensi untuk dikembangkan menjadi industri komponen otomotif yang terkait dengan pemenuhan kebutuhan industri-industri motor dan mobil seperti Honda, Yamaha, Viar dan lain-lain. Produk-produk komponen otomotif merupakan produk strategis karena merupakan bahan baku bagi industri hilirnya (industri kendaraan motor dan mobil). Industri komponen otomotif di Kabupaten Tegal didorong agar dapat mengikuti pertumbuhan sektor otomotif nasional. Selama ini industri komponen otomotif hanya sekedar menghasilkan produk aksesoris yang nilai tambahnya rendah. Ke depannya industri komponen otomotif akan terus dikembangkan dengan membuat komponen-komponen yang merupakan komponen inti kendaraan bermotor, sehingga ada kenaikan nilai tambah yang signifikan. Pertumbuhan industri logam di Kabupaten Tegal dimulai pada masa kolonial Belanda. Cikal bakal bermula dari berdirinya Pabrik Logam NV Barat (sekarang PT. Barata) dan NV Nrunger (PT. Dwika sekarang sudah tutup), sekitar tahun 1918. Pabrik tersebut dibangun untuk menopang kebutuhan peralatan dan suku cadang pabrik gula, perkapalan, kereta api dan tekstil (Laporan Akhir Penyusunan Revisi Rencana Program Investasi Jangka Menengah (RPIJM) Bidang Cipta Karya Kabupaten Tegal, TA. 2018).

Total keseluruhan sentra industri dari kelompok cabang kimia berjumlah 31 unit sentra yang tersebar di 30 desa. Sentra-sentra tersebut berlokasi di desa-desa, yaitu : Desa Kalisasak, Karangdawa, Margasari, Pakulaut, Kaliwadas, Balapulang Wetan, Bandasari, Sulapranan, Bulakpacing, Kabunan, Slarang Lor, Babakan, Jatilawang, Kertaharja, Kertayasa, Tanjungharja, Jatimulya, Tegalandong, Timbangreja, Pagerbarang, Rajegwesi, Bedug, Kalikangkung, Jatibogor, Bengle Dukuhmalang, Kaligayam, Langgen, Wangandawa dan Desa Kedungkelor. Secara garis besar industri dari jenis industri ini adalah industri batu bata dan genteng dari tanah liat dan dalam melakukan proses kegiatan produksinya dimulai dari pengolahan, pencetakan, dan pembakarannya sehingga membutuhkan tempat yang luas dan terbuka. Begitu juga dalam mendapatkan tanah liat yang digunakan sebagai bahan baku. Maka dari itu industri-industri jenis ini sangat cocok untuk berlokasi di sekitar lahan persawahan yang banyak terdapat di kawasan perdesaan yang mayoritas penggunaan lahannya berupa lahan persawahan. Sentra-sentra industri dari kelompok cabang logam dan mesin hanya terkonsentrasi di 3 wilayah kecamatan saja, yaitu Kecamatan Adiwerna, Kecamatan Kramat dan Kecamatan Talang. Total 
keseluruhan sentra berjumlah 15 unit sentra yang tersebar di Desa Lemahduwur, Pesarean, Dampyak, Kajen, Kebasen, Pegirikan, Pesayangan, dan Desa Talang. Sentra-sentra industri ini sudah ada sejak tahun 1980-an yang bertahan hingga sampai sekarang dengan semakin meningkatnya jumlah unit usaha yang ada di sentra-sentra industri ini, dan pada akhirnya telah menjadi ciri khas dari 3 wilayah kecamatan tersebut.

Cabang industri logam dan mesin mempunyai kesamaan dengan cabang aneka yaitu di mana faktor yang mempengaruhi dari volume produksi adalah jumlah unit usaha, jumlah tenaga kerja, nilai invetasi, nilai produksi dan nilai bahan baku. Pada umumnya industri-industri dalam sentra tersebut tumbuh dan berkembang sudah lama dan beroperasi secara turun temurun dari keluarganya. Industri logam dan mesin di Kabupaten Tegal, mayoritas bergerak dalam bidang machining sehingga penggunaan alat teknologi sangat berperan andil dalam pencetakan mesin tersebut. Adanya penggunaan alat-alat produksi yang berteknologi sudah mulai digunakan di jenis industri ini, akan tetapi juga memerlukan kemampuan dari para pekerjanya dalam hal perakitan dan penyiapan bahan baku. Jadi peran dari tenaga kerja juga diperlukan untuk industri jenis ini. Hampir sebagian besar bahan baku yang digunakan dari barang bekas atau logam bekas yang mudah didapatkan dari para pengumpul barang-barang besi atau logam bekas yang ada di luar wilayah Kabupaten Tegal, seperti Jakarta. Sehingga bahan baku tersebut belum mendapatkan standardisasi dan akan berakibat pada kualitas komoditas yang dihasilkan.

Komoditas dari kelompok cabang industri logam dan mesin mempunyai nilai jual atau nilai produksi yang tinggi, karena produkproduknya banyak dijual ke masyarakat sekitar yang berupa komponen/spare part kendaraan bermotor, alat-alat pertukangan dan rumah tangga. Selain itu produk-produknya juga banyak dijual ke industri-industri besar, di mana produk-produknya seperti galangan kapal, industri otomotif, industri alat berat, dan lainnya). Pada umumnya para pengusaha industri cabang logam dan mesin dalam membeli alat dan mesin produksi bekas kemudian direparasi atau diperbaiki kembali dan juga dalam proses operasinya dilakukan di rumah para pemilik usaha industri tersebut. Sehingga investasi yang dikeluarkan hanya sebatas untuk biaya operasional produksi baik dari pembelian bahan baku, biaya tenaga kerja, dan biaya perawatan mesin-mesin produksi. Semakin besarnya nilai investasi bagi industriindustri ini maka akan berpengaruh dengan peningkatan kemampuan dari segi finansial dari industri-industri tersebut (Nuswantoro, 2017, p. 12-14).

Kabupaten Pemalang dikenal juga mempunyai banyak produk unggulan seperti sentra tenun ATBM, konveksi, kerajinan kulit ular, dan sapu glagah, dan masih banyak potensi yang bisa digali di bumi Pemalang tersebut. Kandungan sumber daya alam yang paling potensial di Kabupaten Pemalang khususnya bagian selatan yang terletak di lereng Gunung Slamet adalah berupa Tambang Diorit, Kaolin, Batu Gamping, dan Batu Marmer. Kegiatan ekonomi rakyat yang menjadi andalan di Kabupaten Pemalang adalah industri kecil pakaian jadi atau konveksi dan salah satunya adalah masuknya investor dari Jepang dengan mendirikan pabrik garment untuk memenuhi kebutuhan ekspor tekstil Indonesia. Hasil industri tesktil dan tenun meliputi sarung tenun, sarung palekat, kaos kaki dan goyor. Sementara itu kerajinan gerabah, sapu glagah, kerajinan kulit ular juga telah mampu menembus pasaran ekspor ke singapura dan Malaysia (https://www.pemalangkab.go.id/profilkabupaten-pemalang/)

Sektor Industri di Kabupaten Pekalongan dalam struktur PDRB memberikan kontribusi terbesar yaitu mencapai $26,65 \%$, industri menengah ke atas sebagian besar berupa industri tekstil sarung palekat jumlahnya sekitar 20 unit. Industri ini merupakan industri padat karya yang memiliki tingkat penyerapan tenaga kerja cukup tinggi. Keberadaan industri sarung palekat di Kabupaten Pekalongan belum diimbangi oleh industri penyedia bahan baku yaitu industri pemintalan benang. Jumlah penduduk yang cukup besar selaras dengan ketersediaan tenaga kerja sebagai aset sumber 
daya berharga untuk mendukung berdirinya suatu perusahaan. Industri pemintalan benang baru tersedia dua unit (PT. Pisma Putra Textile dan PT. Watusalam Textile), itu pun kurang lebih $60 \%$ hasil produksi PT. Pisma Putra Textile dimanfaatkan untuk memenuhi kebutuhan perusahaan group sendiri, yaitu PT. Pismatex Textile Industri, sehingga industri lainnya untuk memenuhi kebutuhan bahan baku benang mengimpor dari daerah lain.

Komoditas unggulan Kabupaten Pekalongan yang bergerak di sektor pertanian yang berpeluang dapat dikembangkan lebih lanjut menjadi industri makanan olahan di antaranya buah mangga, salak, manggis, kentang, dan durian. Untuk sektor kelautan/perikanan yang menjadi peluang investasi adalah budidaya udang vanname, industri pengolahan rumput laut dan pengolahan ikan lele asap. Biasanya komoditas tersebut dijual tanpa pengolahan sehingga nilai ekonomis, daya tahan dan masa simpannya masih rendah. Terutama pada saat panen raya, harga komoditas tersebut akan jatuh. Hal ini membuka peluang bagi usaha industri makanan olahan (Buku Potensi dan Peluang Investasi Tahun 2015 Penerbit: Badan Penanaman Modal dan Pelayanan Perizinan Terpadu (BPMPPT) Kab. Pekalongan).

Sedangkan untuk bidang industri, perikanan dan bidang properti Kota Pekalongan dapat dikatakan lebih maju di antara kota-kota lain di Jawa Tengah. Kota Pekalongan memiliki wilayah yang sangat strategis mengingat letaknya di antara Jakarta dan Surabaya. Dilihat dari bidang perikanan, pelabuhan Kota Pekalongan menjadi transit dan daerah yang menjadi area pelelangan hasil tangkapan laut oleh para nelayan dari berbagai daerah sekitar, pelabuhan ini merupakan pelabuhan perikanan terbesar di Pulau Jawa. Selain itu di Kota Pekalongan banyak terdapat perusahaan pengolahan hasil laut, seperti ikan asin, terasi, sarden, dan kerupuk ikan, baik perusahaan berskala besar maupun industri rumah tangga. Berikut beberapa potensi industri yang dapat dikembangkan untuk mendorong keberadaan industri pertahanan Indonesia: (https://pekalongankota.go.id/halaman/geograf i.html)

1. Galangan kapal fiberglass

2. Galangan kapal baja (PT Barokah Marine)

3. Pabrik es balok,

4. Industri ikan asin

5. Industri $\mathrm{p}$ ikan,

6. Pabrik pengalengan ikan Maya Food,

7. Industri kecil pembuatan terasi,

8. Pabrik pembuatan fillet ikan

9. Industri kerajinan batik

10. Industri pembuatan mebel rotan dan bambu

11. Industri kecil makanan ringan

12. Pabrik rokok sigaret kretek tangan

13. Pabrik teh

Berikut disajikan menggunakan tabel deskripsi industri logam mesin kimia (ILMK), industri aneka (IA), dan industri hasil pertanian (IHP) yang terdapat di Kota Pekalongan tahun 2016:

Tabel 1. Industri di Kota Pekalongan

\begin{tabular}{llll}
\hline & $\begin{array}{l}\text { Industri } \\
\text { Kecil }\end{array}$ & $\begin{array}{l}\text { Industri } \\
\text { Menengah }\end{array}$ & $\begin{array}{l}\text { Industri } \\
\text { Besar }\end{array}$ \\
\hline ILMK & 693 & 19 & \\
IA & 2524 & 92 & 3 \\
IHP & 3094 & 49 & 2 \\
JUMLAH & 6311 & 160 & 5
\end{tabular}

Sumber: diolah peneliti

Industri kecil dan menengah mengalami peningkatan jumlahnya bila dibandingkan dengan tahun sebelumnya. Sedangkan Industri besar jumlahnya tidak bertambah bila dibandingkan tahun lalu. Secara total jumlah industri di Kota Pekalongan naik 52 unit $(0,81 \%)$ dari tahun 2015 (Dinas Perindustrian dan Tenaga Kerja Kota Pekalongan).

Menurut penelitian yang dilakukan Tri Mulyono (2016) yang melihat bahwa dari segi produktivitas galangan, Kabupaten Batang merupakan salah satu kabupaten yang memiliki potensi untuk produksi kapal. Hal ini dibuktikan terdapat galangan kapal tradisional yang dimiliki oleh CV. Laksana Abadi yang pada tahun 2000 saja mampu memproduksi kapal sebanyak 18 buah dalam waktu 12 bulan. Selain CV. Laksana Abadi, terdapat CV. Rizki Maulana Bahari yang usahanya bergerak dalam bidang pembuatan kapal kayu. 
Pengerjaan dalam produksinya masih bersifat tradisional dan belum mampu untuk menerapkan proses produksi menggunakan teknologi yang lebih modern. CV ini terdapat di daerah Kelurahan Karangasem Utara, Kecamatan Batang.

Kabupaten Batang memiliki industri tekstil dari skala rumah tangga sampai dengan yang berorientasi ekspor yang tersebar di wilayahnya. PT. Primatex dan PT. Saritex merupakan contoh industri tekstil yang berada dalam administrasi wilayah Batang. Dilihat dari sisi ekonomi karena terdapat jalur perdagangan nasional yaitu jalan Pantura merupakan wilayah yang sangat strategis. Potensi untuk dikembangkan menjadi pelabuhan perikanan ataupun pelabuhan kargo untuk barang hasil produksi industri sekitar merupakan keunggulan tersendiri disebabkan wilayahnya yang memiliki garis pantai yang terhitung panjang.

Jaringan transmisi gas bumi yang menjadi rencana Pemerintah Pusat yang menghubungkan Cirebon ke Gresik jika dianalisa lebih lanjut dapat menjadi potensi tumbuhnya industri besar di sepanjang jalur pipar gas tersebut. Batang memiliki pasokan listrik yang dapat diandalkan karena terdapat jaringan SUTET milik PT. PLN yang melewati wilayahnya. Wilayah Batang yang sangat luas, dengan sejarah bencana geologi yang hampir tidak ada, ditunjang sumber daya manusia yang melimpah akan menguntungkan bagi investor yang hendak membangun industri di wilayah ini dan jika melihat bahwa di wilayah Kabupaten Batang mempunyai potensi energi hidro yang bisa dikembangkan menjadi Pembangkit Listrik Tenaga Mikrohidro (PLTMH) (Bappeda Kabupaten Batang).

\section{KESIMPULAN}

Pemerintah tidak hanya harus menunjukkan keberpihakan dengan menetapkan regulasi dan mengembangkan kebijakan seperti transparansi perencanaan pembelian alutsita dan substitusi impor dalam pengadaan senjata. Pembinaan industri membutuhkan bukan hanya dukungan regulasi dan kebijakan, melainkan juga kebijakan yang terpadu dengan aspek finansial, seperti mendorong industri pendukung agar terintegrasi dan mandiri dari hulu ke hilir, hingga memberikan bantuan modal bagi industri pertahanan. Kepercayaan terhadap industri yang ada untuk mengembangkan diri mengarah ke industri yang efisien dan inovatif menjadi titik pusat dari seluruh dukungan yang diharapkan dari pemerintah. Untuk mewujudkan industri pertahanan yang mampu tumbuh menjadi industri mandiri dan memainkan peran penting sebagai tulang punggung pertahanan diperlukan waktu yang tidak singkat, di samping itu kesabaran dan toleransi yang tinggi sangat dibutuhkan.

Industri pertahanan Indonesia berusaha meningkatkan muatan lokal dengan mengembangkan industri lokal komponen penunjang dan pendukung di dalam negeri. Puncak tangga produksi adalah kemampuan memproduksi sistem senjata yang canggih hasil karya rekayasa sendiri, dengan seluruh komponen penunjang dan pendukung diproduksi di dalam negeri.

Penelitian ini menghasilkan rekomendasi bahwa penting untuk membangun keselarasan dengan klaster industri sipil di dalam negeri, terutama industri manufaktur. Hal ini dapat menjadi pertimbangan Pemerintah Daerah Bregasmalang - Petanglong untuk terus mendorong industri yang ada di wilayah administrasinya untuk dapat mengembangkan diri sebagai industri penunjang dan pendukung industri pertahanan Indonesia.

Potensi industri Kawasan pengembangan Bregasmalang - Petanglong memegang peran yang penting dalam membentuk klaster-klaster industri komponen/pendukung dan bahan baku untuk industri pertahanan Indonesia. Ini merupakan implikasi riset jika melihat kebijakan pemerintah pusat dalam mengembangkan industri pertahanan. Premis utama yang harus disadari, industri pertahanan adalah bagian dari industri nasional. Upaya membangun industri pertahanan akan sangat terkait dan sangat bergantung pada perkembangan klaster-klaster industri sipil nasional secara keseluruhan. 


\section{REFERENSI}

\section{Buku}

Hartanto, Agus. Kajian Kebijakan Alutsista Pertahanan dan Keamanan Republik Indonesia. Jakarta : LIPI Press, 2013.

Karim, Silmy. Membangun Kemandirian Industri Pertahanan Indonesia. Jakarta : Kepustakaan Populer Gramedia, 2014.

Supriyatno, Makmur. Tentang Ilmu Pertahanan. Jakarta : Yayasan Pustaka Obor Indonesia, 2014.

Yusgiantoro, Purnomo. Ekonomi Pertahanan : Teori \& Praktik. Jakarta : PT Gramedia Pustaka Utama, 2014.

\section{Artikel Jurnal}

A.Trimulyono,A.Wibawa, E. S.Hadi, Sumardi, I.Pujo, "Pemberdayaan Masyarakat Pesisir di Kabupatn Batang Jawa Tengah Melalui Pengembangan Industri Galangan Kapal Tradisional," Jurnal Infro, No. 1(Februari 2016, Fakultas Teknik Universitas Diponegoro.

Ahmad Jazuli, "Pembangunan Pertahanan dan Keamanan Demi Penegakan Hukum di Indonesia: Kewibawaan Suatu Negara," Jurnal Penelitian Hukum DE JURE 16, No. 2(Juni2016), Badan Penelitian dan Pengembangan Kemenkumham, 2016, Jakarta.

DOI:

http://dx.doi.org/10.30641/dejure.2016.V1 6.187-199.

Faris Al-Fadhat dan Naufal Nur Aziz Effendi, "Kerjasama Pertahanan Indonesia-Korea Selatan: Kedaulatan Maritim dan Transfer Teknologi dalam Pengadaan Kapal Selam DSME 209/1400," Jurnal Ketahanan Nasional 25, No. 3 (Agustus 2019), Universitas Gadjahmada, 2019. Yogyakarta. DOI: $10.22146 / j k n .48822$.

Helmi Tachejadi Soerjono, Muhamad Nur Affandi, Soni Akhmad Nulhaqim, "Perkembangan Alutsista Satuan Infanteri Pada Prioritas Pembangunan Minimum Essential Force (Mef)," Jurnal Kolaborasi Resolusi Konflik 01, No. 1
(September 2019). Universitas Padjadjaran, 2019, Bandung.

Henrik Heidenkamp, John Louth, dan Trevor Taylor, The Defense Industrial Triptych: Government as Customer, Sponsor and Regulator (Essex: Royal United Services Institute for Defense and Security Studies, 2013.

Ian Montratama, "Strategi Optimalisasi Pengadaan Sarana Pertahanan Bagi Industri Pertahanan Indonesia," Jurnal Pertahanan 04, No. 3 (Desember 2014), Kementerian Pertahanan RI, 2014, Jakarta. DOI: http://dx.doi.org/10.33172/jpbh.v4i3J.342

Lukman Fahmi Djarwono, "Pembangunan Industri Pertahanan Indonesia: Menuju Pemenuhan Target MEF atau Sekedar Menuju Arm Candy," Jurnal Defendonesia 02, No. 2 (Juni 2017). Lembaga Kajian Pertahanan untuk Kedaulatan NKRI, 2015, Jakarta.

Muradi, "Model Pendanaan Industri Pertahanan dan Peningkatan Sumber Daya Manusia," Jurnal Pertahanan 05, No. 2 (Agustus 2015). Kementerian Pertahanan RI, 2015, Jakarta. DOI: http://dx.doi.org/10.33172/jpbh.v5i2.365.

Pebri Tuwanto, "Politik Pembangunan Industri Pertahanan Nasional di Era Global," Jurnal Gema Keadilan 02, No. 1 (September 2015), Universitas Diponegoro, 2015, Semarang DOI: 10.3592/2.

\section{Undang-Undang}

Peraturan Presiden Republik Indonesia Nomor 79 Tahun 2019

Undang-Undang Nomor 16 Tahun 2012 tentang Industri Pertahanan.

\section{Artikel dan Lain Lain}

Bahan Kuliah untuk mata kuliah Industri Pertahanan di Prodi Ekonomi Pertahanan Universitas Pertahanan, disampaikan 12 Maret 2014. 
Bangkit Dwi Nuswantoro,

file:///C:/Users/ASUS/AppData/Local/Te mp/182-356-1-SM.pdf.

$\mathrm{B} u k u$ Potensi dan Peluang Investasi Tahun 2015Penerbit : Badan Penanaman Modal dan Pelayanan Perizinan Terpadu (BPMPPT) Kab. Pekalongan

Dokumen KKIP dalam kuliah di Prodi Ekonomi Pertahanan Universitas Pertahanan, disampaikan 24 Maret 2014.

http://www.brebeskab.go.id, Diakses 20 Mei 2020.

https://bappedapemalang.wordpress.com/cat egory/ekonomi/, Diakses 6 Agustus 2020.

https://batangkab.go.id/?p=2\&id=2, Diakses 6 Agustus 2020.

https://pekalongankota.go.id/halaman/geogr afi.html, Diakses 6 Agustus 2020.

Kathleen A. Walsh, "The Role, Promise, and Challenges of Dual-Use Technologies in
Nasional Defense", dalam Richard A. Bitzinger (editor), The Modern Defense Industri, ABC-CLIO, LLC, California, 2009.

Komite Kebijakan Industri Pertahanan (KKIP), "Paparan Menteri Pertahanan Selaku Ketua Harian KKIP pada Sidang Pertama KKIP”, materi presentasi (Surabaya, 12 Maret 2014).

Laporan AkhirPenyusunan Revisi Rencana Program Investasi Jangka Menengah (RPIJM) Bidang Cipta Karya KABUPATEN TEGAL, TA.2018.

Rapat Harmonisasi RUU Revitalisasi Indhan pada Rabu, 6 Oktober 2010 di Kem Huk \& HAM dalam Kuliah Mata Kuliah Industri Pertahanan Prodi Ekonomi Pertahanan Universitas Pertahanan 8 Maret 2014 